УДК 330.1

DOI: https://doi.org/10.37320/2415-3583/15.11

Скрипник M.I.

доктор економічних наук, професор

Київський начіональний університет технологій та дизайну ORCID: https://orcid.org/0000-0002-6205-0754

Григоревська O.O.

кандидат економічних наук, доцент

Київський національний університет технологій та дизайну ORCID: https://orcid.org/0000-0001-8279-3523

\title{
РИЗИКИ ТА ЗАГРОЗИ ПОДАТКОВОЇ БЕЗПЕКИ ПІДПРИЕМСТВА ТА ШЛЯХИ ÏХ МІНІМІЗАЦІї ПІД ВПЛИВОМ COVID-19
}

\begin{abstract}
Стаття присвячена узагальненню підходів до виділення ризиків та загроз для податкової безпеки підприємства, а також окресленню шляхів їх мінімізаиії під впливом Соvіd-19. У процесі дослідження використовувались методи спостереження, порівняння, аналізу, синтезу, узагальнення. Обтрунтовано, щцо ризики глобальних епідемій, ризики військових конфліктів, ризик дизфункиії системи управління та ризик соціальної нестабільності стали новою загрозою для податкової безпеки. Наведено етапи управління ризиками підприємства, якими є ідентифікація, планування, визначення методів управління ризиками, оцінювання ризику, моніторинг податкових ризиків та аналіз ефективності управління ними. Охарактеризовано методи управління податковим ризиком в умовах Covid-19 (українська практика) та доведено необхідність внесення пропозииій шодо розроблення Фіскальної дорожньої карти відновлення економіки, щяо має включати такі етапи: 1) пандемічний період; 2) постпандемічний період; 3) стабілізачійний період.
\end{abstract}

Ключові слова: ризик, податковий ризик, фіскальна криза, управління ризиками, антикризові заходи.

Постановка проблеми. Глобальна пандемія COVID-19 торкнулась економічного життя більшості суб'єктів господарювання та спричинила структурні коливання у світовій економіці.

Так, відповідно до прогнозів Всесвітнього економічного дайджесту за жовтень 2020 року, до кінця 2020 року очікується скорочення світової економіки на 4,4\% [16]. Водночас 13 жовтня МВФ опублікував «Перспективи розвитку світової економіки», в яких прогнозується скорочення ВВП України на 7,2\% у 2020 році (за прогнозами Міністерства розвитку економіки, торгівлі і сільського господарства, на 5,5\%) [14].

Відповідно до звіту «COVID-19: карта ризиків та наслідків» [2], який висвітлив результати опитування 11860 топ-менеджерів та експертів 3 ризик-менеджменту (з них - 92 з України), було виділено 10 основних бізнес-ризиків, що викликають найбільшу стурбованість у всьому світі і не сприяють економічному зростанню, а саме фінансові кризи; кібератаки; безробіття або неповна зайнятість; ціни на енергоносії неспроможність державного управління; глибока соціальна нестабільність; шахрайство або крадіжка даних; міждержавний конфлікт; податковий криза економіки; спекулятивна манія («економічна бульбашка»). Зниження темпів зростання і збільшення боргу збільшують ймовірність фіскальної кризи, а саме ризику, який респонденти визначили як основну проблему під час ведення бізнесу.

Коли уряди відчувають зростаючий тиск через обмеження доходів і некеровану заборгованість, зазвичай наступає скорочення видатків або підвищення податків для збереження макроекономічної стабільності.

Будь-який $з$ цих заходів впливає перш за все на найбільш уразливі групи населення, якими є громадяни, які залежать від надання суспільних благ і послуг; домогосподарства, дохід яких особливо чутливий до коливань цін; працівники, роботі яких може загрожувати порушення рівноваги ринку праці.

Таким чином, дослідження ризиків та загроз податкової безпеки є актуальним проблемним питанням, а розроблення методів мінімізації їх впливу сприятиме недопущенню реалізації ризику фіскальної кризи.

Аналіз останніх досліджень і публікацій. Вибрана тема дослідження $є$ популярною серед учених та практиків. Так, питанням ідентифікації та шляхам мінімізації ризиків податкової безпеки присвячено праці таких науковців, як Т.Г. Турпак, Я.Я. Назаренко [6], I.В. Горобінська [6], Н.О. Свтушенко [3], Т.Г. Мисник [4], О.В. Безкровний [4], Ю.О. Романченко [4], І.І. Подік [5], Ю.В. Гончаров [5], Чуі Аннет (Chooi Annette) [8]. Дослідниками здійснено вагомий внесок у розвиток підходів до визначення, оцінювання ризиків та управління ними. Проте існує необхідність розвитку підходу до дослідження стану податкової безпеки під впливом новітніх загроз.

Мета статті полягає в дослідженні ризиків та загроз податкової безпеки підприємства та окресленні шляхів їх мінімізації під впливом Covid-19.

Виклад основного матеріалу. Основні висновки, пов'язані з ризиками (витяг огляду позицій керівників 133 країн світу на прикладі 11 країн) наведено у табл. 1. В кожному випадку перераховувались п'ять основних ризиків для кожної економіки, як вважали респонденти.

Фіскальна криза посіла шосте місце у скоригованих результатах за 2020 рік (34\% респондентів), що свідчить про зростаючий неспокій менеджменту щодо слабкості державних фінансів. Це також єдиний ризик, який входить у першу десятку в кожному регіоні, маючи найбільшу частку на Близькому Сході і в Північній Африці (друге місце), а найменшу - в Південній Азії (дев'яте місце). Він також має високий рейтинг у Середній Азії та Україні (4 місце). На внутрішньому рівні фіскальна криза являє собою першу десятку ризиків у 97 зі 133 країн [13]. 
Таблиця 1 - Витяг із опитування 11380 респондентів - представників менеджменту підприсмств 133 країни світу щодо виділення ризиків діяльності у 2020 році (на прикладі 11 країн)

\begin{tabular}{|c|c|c|c|c|c|}
\hline Країна & Ризик 1 & Ризик 2 & Ризик 3 & Ризик 4 & Ризик 5 \\
\hline Австралія & Ціни на енергоносії & Кібератаки & Спекулятивна манія & $\begin{array}{l}\text { Відмова критично } \\
\text { важливої } \\
\text { інфраструктури }\end{array}$ & $\begin{array}{l}\text { Фіскальна криза } \\
(40 \%)\end{array}$ \\
\hline Болгарія & $\begin{array}{l}\text { Екстремальні } \\
\text { погодні явища }\end{array}$ & Терористичні атаки & Некерована інфляція & $\begin{array}{l}\text { Фіскальна криза } \\
(18 \%) \\
\end{array}$ & $\begin{array}{l}\text { Масштабна } \\
\text { вимушена міграція }\end{array}$ \\
\hline Грузія & $\begin{array}{l}\text { Міждержавний } \\
\text { конфлікт }\end{array}$ & Урядова дисфункція & $\begin{array}{l}\text { Дисфункція } \\
\text { державного та } \\
\text { регіонального } \\
\text { управління } \\
\end{array}$ & $\begin{array}{l}\text { Безробіття та } \\
\text { неповна зайнятість }\end{array}$ & $\begin{array}{l}\text { Фіскальна криза } \\
(19 \%), \text { ціни на } \\
\text { енергоносії, } \\
\text { некерована інфляція }\end{array}$ \\
\hline Ірландія & $\begin{array}{l}\text { Дисфункція } \\
\text { місцевого } \\
\text { самоврядування }\end{array}$ & $\begin{array}{l}\text { Фіскальна криза } \\
(43 \%)\end{array}$ & Кібератаки & Спекулятивна манія & Зміна клімату \\
\hline Ісландія & Некерована інфляція & Природні катаклізми & Спекулятивна манія & $\begin{array}{l}\text { Фіскальна криза } \\
(27 \%)\end{array}$ & $\begin{array}{l}\text { Екстремальні } \\
\text { погодні умови }\end{array}$ \\
\hline Кіпр & Спекулятивна манія & $\begin{array}{l}\text { Фіскальна криза } \\
(28 \%)\end{array}$ & $\begin{array}{l}\text { Дисфункція } \\
\text { фінансового сектору }\end{array}$ & $\begin{array}{l}\text { Міждержавний } \\
\text { конфлікт }\end{array}$ & Урядова дисфункція \\
\hline Польща & $\begin{array}{l}\text { Міждержавний } \\
\text { конфлікт }\end{array}$ & Ціни на енергоносії & $\begin{array}{l}\text { Фіскальна криза } \\
(30 \%)\end{array}$ & Кібератаки & Урядова дисфункція \\
\hline Румунія & Урядова дисфункція & $\begin{array}{l}\text { Фіскальна криза } \\
(52 \%)\end{array}$ & $\begin{array}{l}\text { Відмова важливої } \\
\text { інфраструктури }\end{array}$ & Некерована інфляція & $\begin{array}{l}\text { Масштабна } \\
\text { вимушена міграція }\end{array}$ \\
\hline Туреччина & $\begin{array}{l}\text { Фіскальна криза } \\
(65 \%) \\
\end{array}$ & $\begin{array}{l}\text { Міждержавний } \\
\text { конфлікт }\end{array}$ & Некерована інфляція & Урядова дисфункція & $\begin{array}{l}\text { Безробіття та } \\
\text { неповна зайнятість } \\
\end{array}$ \\
\hline Україна & $\begin{array}{l}\text { Соціальна } \\
\text { нестабільність }\end{array}$ & $\begin{array}{l}\text { Ціни на енергоносії, } \\
\text { міждержавний } \\
\text { конфлікт }\end{array}$ & $\begin{array}{l}\text { Фіскальна криза } \\
(41 \%)\end{array}$ & $\begin{array}{l}\text { Відмова критично } \\
\text { важливої } \\
\text { інфраструктури }\end{array}$ & $\begin{array}{l}\text { Безробіття та } \\
\text { неповна зайнятість }\end{array}$ \\
\hline Фінляндія & Кібератаки & Зміна клімату & $\begin{array}{l}\text { Масштабна } \\
\text { вимушена міграція }\end{array}$ & $\begin{array}{l}\text { Безробіття та } \\
\text { неповна зайнятість }\end{array}$ & $\begin{array}{l}\text { Фіскальна криза } \\
(44 \%)\end{array}$ \\
\hline Японія & Природні катаклізми & Кібератаки & $\begin{array}{l}\text { Фіскальна криза } \\
(47 \%)\end{array}$ & $\begin{array}{l}\text { Міждержавний } \\
\text { конфлікт }\end{array}$ & $\begin{array}{l}\text { Екстремальні } \\
\text { погодні умови }\end{array}$ \\
\hline
\end{tabular}

Джерело: складено на основі джерел [11; 13$]$

У кожній організації працівники на всіх рівнях щодня управляють ризиками. Співробітники зважують наявні варіанти та оцінюють відносні ризики перед тим, як вибрати напрям дій. Кожна дія, пов’язана з провадженням господарської діяльності, має елемент ризику. Підприємства використовують внутрішні правила, керівні принципи та процедури для зменшення ризиків, надаючи працівникам вказівки щодо того, як їм слід підходити до вирішення повсякденних завдань. Підприємства визнають, що ризик є невід'ємною частиною ведення бізнесу, його не можна повністю уникати. Однак можна впровадити механізм для систематичного виявлення ризиків та мінімізації шансу (завдяки профілактичній дії) несприятливого впливу у разі матеріалізації ризиків [8].

Так, питання визначення сутності та видів податкових ризиків є суб'єктивною позицією кожного автора, хто проводив свої дослідження у цьому аспекті. Кожна позиція $є$ обгрунтованою $з$ огляду на напрям дослідження. Зупинимось на окремих із них задля порівняння та можливого формування власного підходу.

Так, I.І. Подік та Ю.В. Гончаров до основних податкових загроз відносять «ухилення від сплати податків, корупцію у податкових органах, відтік національного капіталу за кордон, зниження інвестиційної активності, припинення діяльності, збільшення витрат на утримання податків, збільшення податкового боргу, тінізацію економіки» [5].

Т.Г. Мисник, О.В. Безкровний, Ю.О. Романченко мають спільний цікавий підхід та виокремлюють такі джерела податкових ризиків, як фіскальна психологія платника, чинники соціально-економічного характеру, зміни в податковій практиці, недоліки планування та прогнозування, чинники нормативно-правового характеру, галузеві особливості діяльності [4].

Н.О. Свтушенко. у своїх дослідженнях поділяє податкові ризики на ризики, притаманні державі, та ризики, притаманні суб'єкту господарювання. Зупинимось на останніх, якими є ризик збільшення податкового тягаря, ризик мінімізації податків, ризик податкового контролю, ризик карного переслідування [3].

Можемо погодитись із усіма авторськими підходами, оскільки, дійсно, різниця між ними полягає лише у визначенні їх кількості та виділенні ознак класифікації. Ми ж можемо додати, що новою загрозою податковій безпеці стали ризики глобальних епідемій, ризики військових конфліктів, ризик дисфункції системи управління та ризик соціальної нестабільності.

У великому різноманітті методів управління ризиками можна виділити процес управління податковими ризиками, який включає етапи, в основі яких лежить система сучасного ризик-менеджменту, скоригована з урахуванням специфіки ризиків у сфері оподаткування (рис. 1).

Таким чином, управління податковими ризиками $€$ основним механізмом забезпечення податкової безпеки, яке не гарантує повної ліквідації ризиків у системі податкових відносин, але дає змогу знизити ймовірність настання несприятливих наслідків для держави й бізнесу. Початковим етапом управління податковими 


\begin{tabular}{|c|c|}
\hline 1. Планування & 2. Ідентифікація \\
\hline $\begin{array}{l}\text { Включає } \quad \text { вибір } \quad \text { найбільш } \\
\text { оптимальних податкових відносин } \\
\text { і систем оподаткування з огляду на } \\
\text { здійснювані види діяльності }\end{array}$ & $\begin{array}{l}\text { Ідентифікація податкового } \\
\text { ризику, обгрунтування причин їх } \\
\text { ймовірного настання }\end{array}$ \\
\hline 4. Методи управління & $\frac{\nabla}{\text { 3. Оцінка ризиків }}$ \\
\hline $\begin{array}{l}\text { Вибір методу та порядку } \\
\text { управління податковими ризиками } \\
\text { (наприклад, вчасне нарахування та } \\
\text { сплата податків) }\end{array}$ & $\begin{array}{l}\text { Вжиття управлінських заходів } \\
\text { (резервування, передача ризику } \\
\text { тощо), якісний аналіз та кількісна } \\
\text { оцінка податкового ризику }\end{array}$ \\
\hline \begin{tabular}{l}
\multicolumn{1}{l}{} \\
5. Моніторинг податкових ризиків та \\
На основі інформаційного забезпе \\
рівня ризиків, панель ризиків, ка] \\
фактичного впливу ризику, відображ \\
у Звіті про управління, а також \\
податкових показників від запланова
\end{tabular} & $\begin{array}{l}\text { ліз ефективності управління ними } \\
\text { я (паспорт ризику, шкала оцінки } \\
\text { ризиків) проводяться визначення } \\
\text { я інформації про податкові ризики } \\
\text { лізуються відхилення фактичних }\end{array}$ \\
\hline
\end{tabular}

\section{Рисунок 1 - Етапи управління податковими ризиками діяльності підприємства}

Джерело: складено та доповнено на основі опрацюювання джерел $[1 ; 5]$

ризиками є розроблення стратегічних і тактичних планів податкової політики. Далі відбувається оцінювання наявної системи оподаткування, масштабів податкових ризиків для кожного виду діяльності та розроблення прогнозу розвитку подій і плану ліквідації наслідків. За результатами моніторингу здійснюється коригування системи управління податковими ризиками та прийняття рішень. На кожному етапі проводиться проміжний аналіз виконання етапів та поточне коригування дій.

Методи управління податковими ризиками залежать від того, чи переслідується мета забезпечення стратегічної ефективності податкової безпеки в довгостроковому періоді соціально-економічного розвитку або вони спрямовані на вирішення короткострокових завдань i конкретних податкових проблем певного економічного етапу фінансово-господарської діяльності. Ці методи дуже різноманітні, однак вони базуються на єдиних засадах і принципах. Економічні ризики постійно поповнюються й змінюються залежно від навколишнього середовища, з'являються нові види ризиків, що ставить перед економістами нові завдання дослідження теорії і практики економічного розвитку, а також є важливим напрямом розвитку теорії економічної безпеки.

Дайджест «Фіскальний моніторинг за жовтень 2020 року» вивчив досвід країн у боротьбі з кризою та навів дані щодо дій урядів на різних фазах пандемії, щоби врятувати життя, зменшити вплив рецесії та оживити зростання й створення нових робочих місць.

3 початку кризи COVID-19 уряди зосереджувались на тому, щоби зробити все можливе, щоб обмежити іiі наслідки. Величезна фінансова підтримка, що надавалася з початку кризи COVID-19, досягла успіху в захисті людей та збереженні робочих місць. Заходи охорони здоров'я, які стримували поширення вірусу, такі як широкомасштабне тестування, відстеження та інформаційні кампанії, допомогли відновити довіру та створили умови для безпечного відкриття бізнесу. Виплати по безробіттю та субсидії на заробітну плату (як у більшості європейських економік) допомогли зберегти робочі місця чи рівень життя. Грошові перекази були особливо корисні для підтримки працівників 3 низьким рівнем доходу, самозайнятих осіб і тих, хто втратив роботу. Підтримка ліквідності фірм запобігла хвилі неплатежів та масових звільнень. Це особливо важливо для малих та середніх фірм, які становлять велику частку. Хоча глобальна фіскальна реакція на кризу була безпрецедентною, відповіді окремих країн визначались їхнім доступом до запозичень, а також рівнем державного та приватного боргу, що вступав у кризу [10].

Щодо української практики, то основні заходи наведемо у табл. 2.

Таким чином, наведені заходи у відповідь на пандемію коронавірусу (COVID-19) були спрямовані на підтримку бізнесу протягом карантинного періоду та запроваджували податкової пільги, такі як спрощені штрафи та відсотки з простроченням платежів, спрощене нарахування та сплата податків і зборів, тимчасове звільнення спеціальних медичних товарів для Covid-19 від сплати ПДВ та митних зборів, спрощення податкових перевірок [15].

Щодо подальших заходів, то в межах виходу з постпандемічної кризи урядам країн пропонують розробити Фіскальну дорожню карту відновлення економіки [12].

Оскільки економіка тимчасово відкривається, але зберігається невизначеність щодо ходу пандемії, уряди повинні стежити за тим, щоб фінансова підтримка не припинялася занадто швидко. Однак вона має стати більш виборчою та не заважати необхідному галузевому перерозподілу за ступенем відновлення діяльності.

Основні етапи дорожньої карти повинні включати такі заходи.

1 Eman: Період пандемії.

1.1. Захист старих робочих місць та повернення людей до роботи за рахунок скорочення програм збереження робочих місць (субсидій до заробітної плати), повторного введення вимог до пошуку роботи 
Таблиця 2 - Методи управління податковими ризиками в умовах Covid-19 (українська практика)

\begin{tabular}{|c|c|}
\hline Вид & Рішення \\
\hline $\begin{array}{l}\text { Мито та інші податки на } \\
\text { імпортні операції }\end{array}$ & $\begin{array}{l}\text { пеціальні медичні товари для Covid-19 тимчасово звільнені від митних зборів з } 1 \text { березня } \\
20 \text { року по } 30 \text { червня } 2020 \text { року. }\end{array}$ \\
\hline $\begin{array}{l}\text { Подовження терміну } \\
\text { подачі звітності/ } \\
\text { здійснення податкових } \\
\text { платежів }\end{array}$ & $\begin{array}{l}\text { Відбулося вжиття таких заходів: } \\
\text { - спрощена система нарахування штрафів та відсотків за несвоєчасну сплату на період з } 1 \\
\text { березня } 2020 \text { року по } 31 \text { травня } 2020 \text { року; } \\
\text { - штрафні санкції не застосовуються, крім випадків нарахування, декларування та сплати ПДВ } \\
\text { та акцизного податку; } \\
\text { - за період } 1 \text { березня } 2020 \text { року по } 30 \text { квітня } 2020 \text { року штрафні санкції не застосовуються за } \\
\text { несвоєчасне подання єдиних звітів про ПДФО та несвоєчасну сплату єдиного соціального внеску; } \\
\text { - спрощене нарахування та сплата податків та зборів (за період з } 1 \text { березня } 2020 \text { року по } 31 \\
\text { березня } 2020 \text { року плата за земельний податок та орендна плата за державне та комунальне } \\
\text { майно, що використовується у підприємницькій діяльності, не стягується; земельний податок } \\
\text { та орендні платежі за квітень } 2020 \text { року нараховуються звичайним способом із відстрочкою } \\
\text { платежу до } 30 \text { червня } 2020 \text { року; існує можливість подати податкову декларацію, щоб } \\
\text { вимагати коригування суми податку; нежитлове нерухоме майно, що належить фізичним } \\
\text { або юридичним особам, не оподатковується, а індивідуальні підприємці, фізичні особи, що } \\
\text { здійснюють незалежну професійну діяльність, та члени приватних фермерських господарств } \\
\text { мають бути звільнені від обчислення та сплати єдиного соціального внеску для себе). }\end{array}$ \\
\hline $\begin{array}{l}\text { Призупинення податкових } \\
\text { перевірок }\end{array}$ & $\begin{array}{l}\text { На період з } 18 \text { березня } 2020 \text { року по } 31 \text { травня } 2020 \text { року діяв мораторій на документальні } \\
\text { та планові податкові перевірки, за винятком перевірок запитів на повернення ПДВ. Планові } \\
\text { перевірки, які слід було розпочати в цей період згідно з графіком } 2020 \text { року, відкладалися. } \\
\text { Податкові перевірки, які вже розпочалися, були тимчасово призупинені до } 31 \text { травня } 2020 \text { року. }\end{array}$ \\
\hline $\begin{array}{l}\text { ПДВ та інші непрямі } \\
\text { податки }\end{array}$ & $\begin{array}{l}\text { Спеціальні медичні товари для COVID-19 тимчасово звільняються від оподаткування ПДВ з } 1 \\
\text { березня } 2020 \text { року по } 31 \text { травня } 2020 \text { року. }\end{array}$ \\
\hline
\end{tabular}

Джерело: складено на основі джерела [9]

й навчання новим навичкам, але з урахуванням допомоги ліквідним, однак все ще вразливим компаніям.

1.2. За низьких процентних ставок і високого рівня безробіття збільшення державних інвестицій починаючи з технічного обслуговування і нарощування проєктів, що може створювати робочі місця й стимулювати економічне зростання.

1.3. Для країн з ринком, що формується, і країн з низькими доходами (зокрема, Україна), висунуто пропозицію зі зміни пріоритетів витрат і підвищення їх ефективності. Деяким можуть знадобитися додаткова офіційна фінансова підтримка й полегшення боргового тягаря.

1.4. Урядам слід вжити заходів для поліпшення дотримання податкових вимог і розглянути можливість підвищення податків для більш заможних груп населення та високоприбуткових компаній. Отримані доходи допоможуть оплачувати критично важливі послуги, такі як системи охорони здоров'я та соціального захисту, під час кризи, яка непропорційно завдає шкоди біднішим верствам суспільства.

2 Eman. Постпандемічний етап.

2.1. Пріоритетом $є$ інвестування в систему охорони здоров'я та освіти.

2.2. Укріплення мережі соціального захисту.

3. Eman. Стабілізаційний етап.

3.1. Перехід до низьковуглецевої та цифрової економіки.
3.2. Встановлення цін на викиди вуглецю для стимулювання людей скорочувати використання енергії та переходити на чисті альтернативи й генерування додаткового доходу [10].

Отже, оскільки країни прагнуть відновити свої державні фінанси, податки відіграватимуть ключову роль як з точки зору рівня доходів, так і з точки зору податкової структури, яку, можливо, необхідно буде адаптувати до Постковідної епохи. Однак менеджменту підприємств та органам державної влади слід враховувати, що кращий спосіб збільшення податкових надходжень - це підтримка стійкого зростання, зокрема за допомогою досить сильних і стійких стимулів, оскільки це приведе до збільшення податкових надходжень [12].

Висновки. Загалом варто зазначити, що функціонування суб'єктів господарювання схильне реагувати на ризики та загрози, генеровані як зовнішнім, так і внутрішнім підприємницьким середовищем. Наведено етапи управління податковими ризиками підприємства, такі як ідентифікація, планування, визначення методів управління податковими ризиками, оцінювання податкового ризику, моніторинг податкових ризиків та аналіз ефективності управління ними. Наведено пропозиції в межах виходу з постпандемічної кризи щодо розроблення Фіскальної дорожньої карти відновлення економіки, що сприятиме недопущенню реалізації ризику фіскальної кризи.

\section{Список використаних джерел:}

1. Вигівська І.М. Бухгалтерський облік діяльності підприємств в умовах ризику: організація та методика : дис. ... канд. екон. наук : спец. 08.00.09 ; Житомирський державний технологічний університет. Житомир, 2009. 372 с.

2. Влияние пандемии: обзор глобальных рисков. URL: https://coronavirus.marsh.com/ru/ru/insights/research-and-briefings/ covid-19-risks-outlook-preliminary-mapping-and-implications.html (дата звернення: 04.12.2020).

3. Свтушенко Н.О. Податкові ризики та система керування ними. Вісник Дніпропетровського університету. Серія : Менеджмент інновацій. 2016. Вип. 6. С. 68-77.

4. Мисник Т.Г., Безкровний О.В., Романченко Ю.О. Податкові ризики: характеристика та шляхи мінімізації. Актуальні проблеми економіки. 2016. № 6(180). С. 158-166. 
5. Подік І.І., Гончаров Ю.В. Податкова складова економічної безпеки України : монографія. Київ : Інтерсервіс, 2017.210 с.

6. Турпак Т.Г., Назаренко Я.Я., Горобінська І.В. Податкова безпека транспортних підприємств. Економіка та держава. 2020. № 9. C. 59-63. DOI: 10.32702/2306-6806.2020.9.59

7. Удосконалення податкової системи України в контексті викликів та загроз, спричинених поширенням COVID-19 : aналітична записка / заг. ред. О.В. Драган, С.М. Брехова, О.І. Нагорічної. Ірпінь : Міністерство фінансів України, Університет ДФС України, Науково-дослідний інститут фіскальної політики, 2020. 96 с.

8. Chooi A. Improving Tax Compliance Establishing a Risk Management Framework. The Governance Brief. 2020. № 39. 32 p.

9. COVID-19 Global Tax Developments Summary Updated as of November 29, 2020. URL: https://assets.kpmg/content/dam/ kpmg/us/pdf/2020/03/covid-19-tax-developments-summary.pdf?nv (дата звернення: 04.12.2020).

10. Fiscal Policy for an Unprecedented Crisis. URL: https://blogs.imf.org/2020/10/14/fiscal-policy-for-an-unprecedented-crisis (дата звернення: 04.12.2020).

11. Global Average Risks \& Sectors 2020. URL: https://widgets.weforum.org/regionalrisks2020/home.html\#risksectors (дата звернення: 04.12.2020).

12. OECD Policy Responses to Coronavirus (COVID-19). Tax and fiscal policy in response to the Coronavirus crisis: Strengthening confidence and resilience. Updated 19 May 2020. URL: https:/www.oecd.org/coronavirus/policy-responses/tax-and-fiscal-policy-inresponse-to-the-coronavirus-crisis-strengthening-confidence-and-resilience-60f640a8 (дата звернення: 04.12.2020).

13. Regional Risks for Doing Business 2020. Insight Report. URL: https:/www.mmc.com/content/dam/mmc-web/insights/ publications/2019/oct/Regional_Risks_For_Doing_Business_WEB\%20FINAL.pdf (дата звернення: 04.12.2020).

14. The Covid-19 crisis in Ukraine 17 November 2020. URL: https://www.oecd.org/eurasia/competitiveness-programme/easternpartners/COVID-19-CRISIS-IN-UKRAINE.pdf (дата звернення: 04.12.2020).

15. Ukraine: Tax relief measures, responding to coronavirus (COVID-19) March 26, 2020. URL: https://home.kpmg/us/en/home/ insights/2020/03/tnf-ukraine-tax-relief-measures-coronavirus.html (дата звернення: 04.12.2020).

16. World Economic Outlook, October 2020: A Long and Difficult Ascent. October 2020. URL: https://www.imf.org/en/ Publications/WEO/Issues/2020/09/30/world-economic-outlook-october-2020 (дата звернення: 04.12.2020).

\section{References:}

1. Vigivska I.M. (2009) Bukhhalterskyi oblik diialnosti pidpryiemstv v umovakh ryzyku: orhanizatsiia ta metodyka [Accounting of enterprises in conditions of risk: organization and methodology] (PhD Thesis), Zhytomyr: Zhytomyrskyi derzhavnyi tekhnolohichnyi universytet.

2. Vliyanye pandemy: obzor globalnyh ryskov [Impact of a pandemic: an overview of global risks]. URL: https://coronavirus.marsh.com/ru/ru/insights/research-and-briefings/covid-19-risks-outlook-preliminary-mapping-and-implications.html (accessed 04 December 2020).

3. Yevtushenko N.O. (2016) Podatkovi ryzyky ta systema keruvannya nymy [Tax risks and their management system]. Visnyk Dnipropetrovskogo universy'tetu. Seriya: Menedzhment innovacij, vol. 6, p. 68-77.

4. Mysnyk T.G., Bezkrovnyj O.V, Romanchenko Yu.O. (2016) Podatkovi ryzyky: kharakterystyka ta shliakhy minimizatsii [Tax risks: characteristics and ways of minimization]. Aktualni problemy ekonomiky, no. 6(180), p. 158-166.

5. Podik I.I., Goncharov Yu.V. (2017) Podatkova skladova ekonomichnoyi bezpeky' Ukrayiny [Tax component of economic security of Ukraine]. Kyiv: Interservis. (in Ukrainian)

6. Turpak T.G., Nazarenko Ya.Ya., Gorobins'ka I.V. (2020) Podatkova bezpeka transportnyh pidpryemstv [Tax security of transport enterprises]. Ekonomika ta derzhava, no. 9, p. 59-63. DOI: 10.32702/2306-6806.2020.9.59

7. Dragan O.V., Brehova S.M., Nagorichnoyi O.I. (eds.) (2020) Udoskonalennia podatkovoi systemy Ukrainy v konteksti vyklykiv ta zahroz, sprychynenykh poshyrenniam COVID-19: analitychna zapyska [Improving Ukraine's tax system in the context of challenges and threats caused by the spread of COVID-19: an analytical note]. Irpin: Ministerstvo finansiv Ukrainy, Universytet DFS Ukrainy, Naukovo-doslidnyi instytut fiskalnoi polityky. (in Ukrainian)

8. Chooi A. (2020) Improving Tax Compliance Establishing a Risk Management Framework. The Governance Brief, no. 39,32 p.

9. COVID-19 Global Tax Developments Summary Updated as of November 29, 2020. URL: https://assets.kpmg/content/dam/ kpmg/us/pdf/2020/03/covid-19-tax-developments-summary.pdf?nv (accessed 04 December 2020).

10. Fiscal Policy for an Unprecedented Crisis. URL: https://blogs.imf.org/2020/10/14/fiscal-policy-for-an-unprecedented-crisis (accessed 04 December 2020).

11. Global Average Risks \& Sectors2020. URL: https://widgets.weforum.org/regionalrisks2020/home.html\#risksectors (accessed 04 December 2020).

12. OECD Policy Responses to Coronavirus (COVID-19). Tax and fiscal policy in response to the Coronavirus crisis: Strengthening confidence and resilience. Updated 19 May 2020. URL: https://www.oecd.org/coronavirus/policy-responses/tax-and-fiscal-policy-in-response-to-the-coronavirus-crisis-strengthening-confidence-and-resilience-60f640a8 (accessed 04 December 2020).

13. Regional Risks for Doing Business 2020. Insight Report. URL: https://www.mmc.com/content/dam/mmc-web/insights/publications/2019/oct/Regional_Risks_For_Doing_Business_WEB\%20FINAL.pdf (accessed 04 December 2020).

14. The Covid-19 crisis in Ükraine 17 November 2020. URL: https://www.oecd.org/eurasia/competitiveness-programme/eastern-partners/COVID-19-CRISIS-IN-UKRAINE.pdf (accessed 04 December 2020).

15. Ukraine: Tax relief measures, responding to coronavirus (COVID-19) March 26, 2020. URL: https://home.kpmg/us/en/home/ insights/2020/03/tnf-ukraine-tax-relief-measures-coronavirus.html (accessed 04 December 2020).

16. World Economic Outlook, October 2020: A Long and Difficult Ascent. October 2020. URL: https://www.imf.org/en/Publications/WEO/Issues/2020/09/30/world-economic-outlook-october-2020 (accessed 04 December 2020). 
Skrypnyk Margaryta, Hryhorevska Olena

Kyiv National University of Technology and Design

\section{RISKS AND THREATS OF TAX SECURITY OF THE ENTERPRISE AND WAYS OF THEIR MINIMIZATION UNDER THE INFLUENCE OF COVID-19}

The purpose of the article is to study the risks and threats to tax security of the enterprise and outline ways to minimize them under the influence of David-19. In the process of research the methods of observation, comparison, analysis, synthesis, and generalization were used. The study is based on the hypothesis that the identification of tax security risks will increase the validity, efficiency and analytical information on their management and develop measures to minimize the impact of COVID-19 on business activities in accordance with modern management requirements. The article presents threats to doing business. It is established that the "Fiscal Crisis" ranked sixth in the adjusted results for 2020 (34\% of respondents). It is substantiated that the risks of global epidemics, risks of military conflicts, and the risk of dysfunction of the management system have become a new threat to tax security; and the risk of social instability. The stages of risk management of the enterprise are given: identification, planning, management methods, risk assessment, monitoring of tax risks and analysis of the effectiveness of their management. The methods of tax risk management in the conditions of Covid-19 (Ukrainian practice in terms of duties and other taxes on import transactions; extension of the deadline for filing reports/making tax payments; suspension of tax inspections; value added tax and other indirect taxes) are characterized and the necessity of introduction of offers on development of the Fiscal road map of economic recovery is proved. Which should include the following stages: Stage 1: Pandemic period; Stage 2. Postpandemic; Stage 3. Stabilizing. It is concluded that countries are seeking to restore their public finances, and that taxes will play a key role, both in terms of income levels and in terms of the tax structure, which may need to be adapted to the Post-Age period. And business management and public authorities should keep in mind that the best way to increase tax revenues is to support sustainable growth, including through strong and sustainable incentives, as this will increase tax revenues.

Key words: risk, tax risk, fiscal crisis, risk management, anti-crisis measures.

JEL classification: D99, G18, M21 